\title{
JE LIBO 3, 6, NEBO 12? \\ DEPOT BRONZOVÝCH NÁPAŽNÍKŮ Z ROSIC (OKR. BRNO-VENKOV)
}

\section{Ivan Čižmář - David Parma*}

*Ústav archeologicképamátkové pécé Brno,v.vi.i.,Kaloudova1321/30,61400 Brno,cizman@uapp.č,parma@uapp.cz.

\begin{abstract}
Would you like 3, 6, or 12? The hoard of bronze armlets from Rosice (dis. Brno-venkov). The hoard of six bronze armlets dated according to analogy in Ha B1 was picked up in cadastre of Rosice in 2020 on the locality of a not-known archaeological site. These artefacts belong to the specific group of jewellery with a centre of occurrence in Central Moravia and they are known exclusively from hoards. It is a good example of a personal deposit of jewellery with strong symbolic connotation similar to analogous hoards from Jabloňany and Plavecké Podhradie.
\end{abstract}

Keywords: hoard, circular jewellery, Final Bronze Age, Moravia

Abstrakt: V roce 2020 byl v katastru Rosic, mimo jakoukoliv známou archeologickou lokalitu, vyzvednut depot šesti bronzových nápažníků, datovatelný dle analogií do stupně Ha B1. Ty patř́ do specifické skupiny šperků s centrem výskytu na střední Moravě, které pocházejí takřka výhradně z depozit. Spolu se zcela analogickými depoty z Jabloňan a Plaveckého Podhradí jde o dobrý prŕklad osobních obětin šperku se silnou symbolickou konotací.

Klíčová slova: depot, kruhový šperk, pozdní doba bronzová, Morava

https://doi.org/10.46283/musarch.2020.2.03

\section{1. Úvod}

V posledním desetiletí představují prezentace nových nálezů pravěkých kovových depozit již standardní náplň odborných periodik, a to zejména pokud jsou věnována specificky tematice doby bronzové (např. Malach - Štrof Hožék 2016; Salaš-Jarưskeová 2017; Navrátil 2010). Jde o nevyhnutelný důsledek postupné akceptace již několik desetiletí se rozvíjející paralelní aktivity široké veřejnosti - uživatelů detektorů kovů, kterou lze v našich podmínkách jen obtížně regulovat restrikcí. Jako dlouhodobě udržitelné se jeví spíše snahy o začlenění amatérských hledačů do oficiálních struktur různými formami spolupráce, často především na osobní a regionální úrovni, která však může být komplexněji podchycena i v rámci větších územních celků (pro Jihomoravský kraj nejnověji Komorócsyy et al. 2019). Právě takto se však dostávají do oficiálních sbírek desítky nových nálezových souborů různé kvality i kvantity, které díky své početnosti (i přes některé zápory vyplývající ze spolupráce s amatérskými spolupracovníky) představují nezanedbatelný korektiv dř́vějších pozorování, postavených dosud především na základě celků $\mathrm{z}$, doby předdetektorové“ (pro Moravu Salaš 2005; k tomu srovnej zjištění celkem 48 nových depozit v regionu Malé Hané k roku 2017: Salaš - Jariškeová 2017). Několik nových celků včetně zde prezentovaného nálezu z Rosic umožňuje detailněji popsat a komentovat pozoruhodnou skupinu značně unifikovaných depozit jediného typu masivního kruhového šperku z pozdní doby bronzové. Autoři na tomto místě musí především vřele poděkovat nálezci za předání a ochotnou součinnost při zjišt’ování nálezových okolností a dále také Juraji Bartíkovi za připomínky a poskytnutí grafických podkladů. 


\section{Nálezové okolnosti}

V posledních dnech měsíce března 2020 ohlásil pan Jan Svoboda ${ }^{1}$ z Rosic nález depotu bronzových náramků, které našel při procházce s detektorem kovů v lese u Rosic. Nálezce bohužel předměty ihned vyzvedl bez předchozí dokumentace jejich uložení; jde o častou chybu prvonálezců, kteř́ jsou však bez výjimky vzápětí odborně poučeni $\mathrm{o}$ náležitém postupu $\mathrm{v}$ prrípadě eventuálního dalšího nálezu. Den po ohlášení byl realizován pracovníky Ústavu archeologické památkové péče Brno výjezd kvưli nezbytnému zaznamenání místa a dalších prípadných okolností nálezu. Při předání nalezených předmětů vyšlo najevo, že jde o šest poměrně masivních nápažníků s bohatou rytou výzdobou, které je možné datovat do pozdní doby bronzové.

Místo nálezu se nachází na úpatí zalesněného hřbetu mezi obcemi Ríčany, Ř́ćčky a Zastávka u Brna, který tvoří jihozápadní část masivu Hvozdecké pahorkatiny (obr.1A: 1). Jde o svah obrácený k jihu, nález pak byl učiněn na jeho úpatí, v trati zvané Okrouhlík. Necelých 200 m jihozápadně při vyústění Chroustovského údolí protéká ríčka Bobrava, soutok s príitokem Bílá voda na okraji Mariánského údolí se nachází cca 500 m jižně od místa nálezu.

Na místě nálezu byla zaměřena poloha výkopu a proběhla jeho dokumentace (obr. 1B). Depot se již bohužel nepodařilo zaznamenat $\mathrm{v}$ jeho původním uložení, dle ústního sdělení nálezce však nápažníky byly uloženy pohromadě, nikoliv ale uspořádány na sobě. $V$ místě určeném nálezcem byla provedena menší sondáž, při které nebyly zjišsěny žádné náznaky zahloubeného objektu či jiné struktury, jež by mohly s depotem souviset. V hnědé až rezavé kamenité hlíně se neprojevovaly žádné anomálie. Rovněž při detektorové prospekci prováděné v bezprostřední blízkosti i v širším okolí nálezu nebyly zaznamenány žádné další předměty či situace související s depotem. S ohledem na skutečnost, že archeologické nálezy získané soukromými osobami jsou majetkem kraje místně př́slušného k nálezu, přešly nabyté předměty do sbírek Muzea Brněnska, kde jsou uloženy pod inv. č. 261/20-1 až 6 .

\section{1. Popis nálezů}

261/20-1. Otevřený tyčinkovitý nápažník plankonvexního profilu, nezúžené, rovně seříznuté konce lehce dorsálně ovalené, bohatá rytá výzdoba ve třech polích - na středu pole s dvojicí klikatkových rýžkami vyplněných krokvic, po oddělení obrveným svazkem dvojitých príičných rýh následuje pole s dvojicí rýžkami vyplněných krokvic tvořících písmeno X, doplněných liniemi bodů; u konce trojice a čtveřice př́ičných rýh; na obou bocích používáním vyhlazené podélné nepravidelné fasety, částečně setřena výzdoba; vnější rozměr $100 \times 79 \mathrm{~mm}$, profil $12 \times 7 \mathrm{~mm}$, váha $118 \mathrm{~g}$; obr. 2: 1;

261/20-2. Otevřený tyčinkovitý nápažník plankonvexního profilu, nezúžené, rovně seříznuté konce lehce dorsálně ovalené, bohatá rytá výzdoba ve třech polích - na středu pole s dvojicí klikatkových rýžkami vyplněných krokvic, po oddělení obrveným svazkem dvojitých př́ičných rýh následuje pole s dvojicí rýžkami vyplněných krokvic tvořících písmeno X, doplněných liniemi bodů; u konce trojice a čtveřice př́íných rýh; uprostřed vnitřní strany dvojice šikmých rýžek; na obou bocích používáním vyhlazené podélné nepravidelné fasety, částečně setřena výzdoba; vnější rozměr $103 \times 82 \mathrm{~mm}$, profil $11 \times 6 \mathrm{~mm}$, váha $113 \mathrm{~g}$; obr. 2: 2;

261/20-3. Otevřený tyčinkovitý nápažník plankonvexního profilu, nezúžené, rovně seříznuté konce lehce dorsálně ovalené, bohatá rytá výzdoba ve třech polích - na středu pole s dvojicí klikatkových rýžkami vyplněných krokvic, po oddělení obrveným svazkem dvojitých prýíčých rýh následuje pole s dvojicí rýžkami vyplněných krokvic tvořících písmeno X, doplněných liniemi bodů; u konce trojice a čtveřice prúíných rýh; uprostřed vnitřní strany dvojice šikmých rýžek; na obou bocích používáním vyhlazené podélné nepravidelné fasety, částečně setřena výzdoba; vnější rozměr $150 \times 88 \mathrm{~mm}$, profil $11 \times 6 \mathrm{~mm}$, váha $107 \mathrm{~g}$; obr. 2: 3;

261/20-4. Otevřený tyčinkovitý nápažník plankonvexního profilu, nezúžené, rovně seř́íznuté konce lehce dorsálně ovalené, bohatá rytá výzdoba - na středu svislé rýhy rozdělené do motivu větvičky, lemováno klikatkou, dále ke konci rýžkami vyplňované krokvice tvořících písmeno $\mathrm{X}$, šikmo obrvený svazek príčných rýh a u konce trojice a čtveřice příčných rýh; na obou bocích používáním vyhlazené podélné nepravidelné fasety; vněšši rozměr $112 \times 87$ $\mathrm{mm}$, profil $11 \times 6 \mathrm{~mm}$, váha $116 \mathrm{~g} ;$ obr. 2: 4;

1 Nálezci patří vřelý dík za předání nálezů a ochotnou součinnost při zjišt'ování nálezových okolností 




Obr. 1. Rosice 1. A - Poloha depotu a další lokality v okolí: 1 - Rosice 1; 2 - Litostrov - Kozí hřbet; 3 - Zastávka 1; 4 Tetčice - býv. Růžičkova cihelna; 5 - Tetčice - Křiby; B - dokumentace místa nálezu depotu; C - depot před konzervací. Fig. 1. Rosice 1. A - The site of the hoard and next sites in surroundings: 1 - Rosice 1; 2 - Litostrov - Kozí hřbet; 3 Zastávka 1; 4 - Tetčice - form. Růžičkova cihelna; 5 - Tetčice - Křiby; B - documentation of the place of discovery of the hoard; $\mathrm{C}$ - the hoard before conservation.

261/20-5. Otevřený tyčinkovitý nápažník plankonvexního profilu, nezúžené, rovně seříznuté konce lehce dorsálně ovalené, bohatá rytá výzdoba sestává z pravidelně rozmístěných svazků příčných rýh s obrvením na jedné straně šikmým, na druhé kolmým, na koncích svazky příčných rýh s jednostranným obrvením; uprostřed vnitřní strany jedna kolmá rytá rýžka; na obou bocích používáním vyhlazené podélné nepravidelné fasety; vnější rozměr $122 \times 80$ mm, profil $13 \times 8$ mm, váha 158 g; na zakončení se dochoval kousek hmoty z organického materiálu (obr. 1C), který byl odeslán k odbornému určení s podezřením na přítomnost blíže nespecifikované textilie. Za použití mikroskopu 


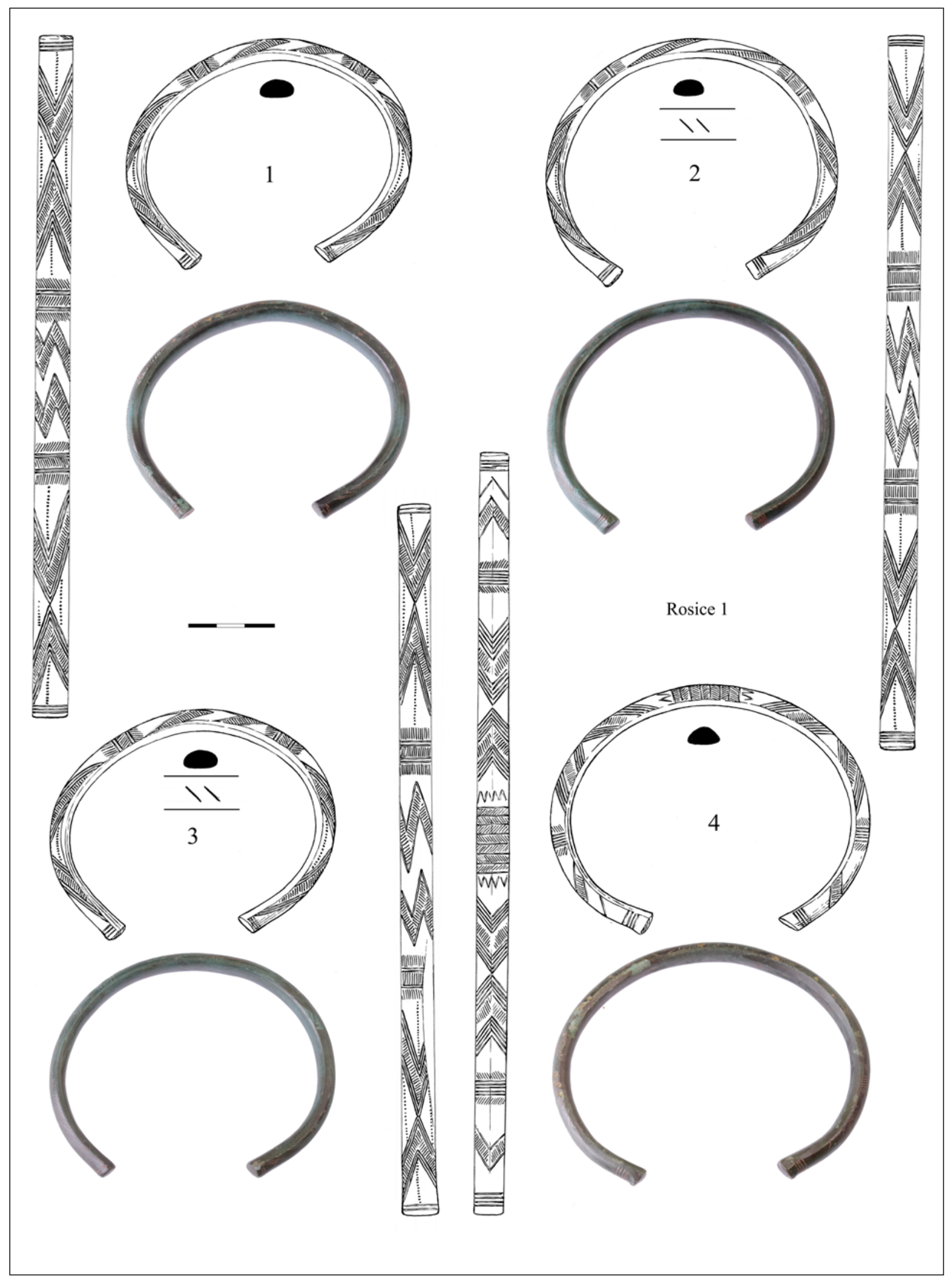

Obr. 2. Rosice 1. Depozitum z roku 2020.

Fig. 2. Rosice 1. Deposit of the 2020. 


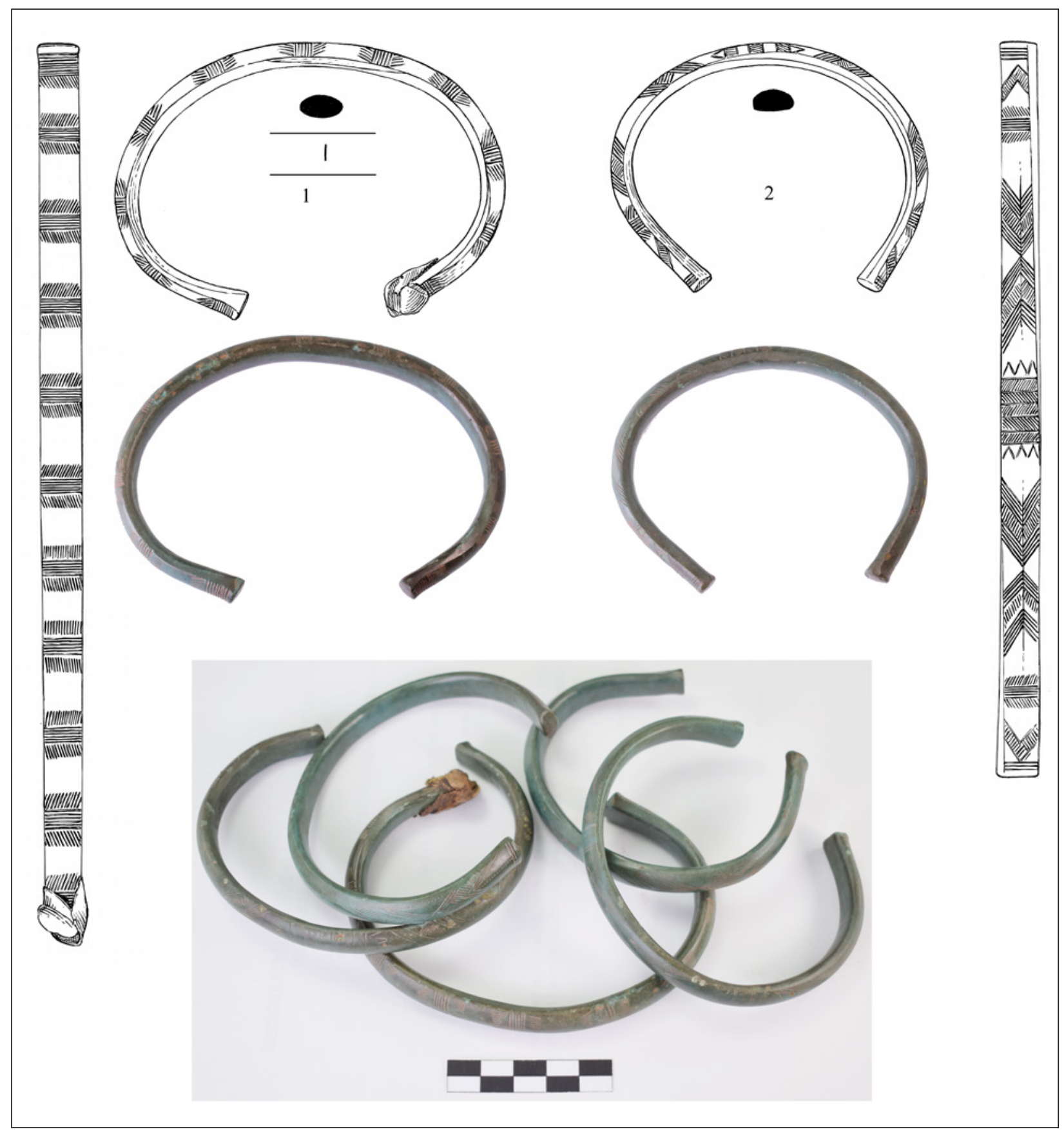

Obr. 3. Rosice 1. Depozitum z roku 2020.

Fig. 3. Rosice 1. Deposit of the 2020.

byl vzorek přezkoumán a L. Kaňáková Hladíková pomocí srovnávacích vzorků spolehlivě potvrdila, že se jedná o zbytky kořene blíže nespecifikované rostliny; obr. 3: 1;

261/20-6. Otevřený tyčinkovitý nápažník plankonvexního profilu, nezúžené, rovně seříznuté konce lehce dorsálně ovalené, bohatá rytá výzdoba - na středu svislé rýhy rozdělené do motivu větvičky, lemováno klikatkou, dále ke konci rýžkami vyplňované krokvice tvořících písmeno $\mathrm{X}$, šikmo obrvený svazek prríčných rýh a u konce trojice a čtveřice prríčných rýh; na obou bocích používáním vyhlazené podélné nepravidelné fasety; vnější rozměr $98 \times 77$ $\mathrm{mm}$, profil $12 \times 7 \mathrm{~mm}$, váha $112 \mathrm{~g} ;$ obr. 3:2. 


\section{Prostorový kontext}

Depozitum bylo uloženo na mírném jihovýchodním svahu jednoho z řady návrší bez výraznějších geomorfologických anomálií v nadmořské výšce $350 \mathrm{~m}$ (obr. 1A: 1). Nejde o výrazný orientační bod v krajině, v okolí nejsou patrné žádné skalní výstupy či jiné útvary prítahující prípadnou pozornost. Vzhledem k poloze a absenci dalších nálezů v okolí patnně depot není součástí současné sídelní komponenty. Ve vzdálenosti přibližně $500 \mathrm{~m}$ jihozápadním směrem se na protilehlém břehu Bobravy nachází menší opevněná výšinná poloha Litostrov - Kozí hřbet (obr. 1A: 2), z níž byly opakovaně získány pouze nálezy z doby halštatské (Čǐ̌már 2004, 166-167). Z blízkosti nálezu nejsou známy žádné lokality z doby bronzové, ovšem jejich př́tomnost nelze vyloučit. Nejbližším dokladem aktivity z pozdní doby bronzové je poměrně signifikantně depot ze Zastávky, nalezený v roce 1924 přibližně 2,2 km jihojihozápadně od nálezu z roku 2020 (obr. 1A: 3; Salaš 2005, 468-470, tab. 466-473). Obsahuje v podstatě pouze šperky různého druhu a jeho součástí je i 21 kusů nápažníků shodných s kusy z Rosic. Další rámcově současné depoty Tetčice 1 a 2 byly odkryty v meziválečném období přibližně $4,5 \mathrm{~km}$ jihovýchodně, a to patrně v prostoru sídliště $\mathrm{v}$ bývalé Růžičkově cihelně (obr. 1A:4). S ním nejspíše pruímo souvisí žárové pohřebiště na Křibech (obr. 1A:5) s těžištěm v mladší době bronzové, z něhož pochází i hrob 3/1964 z pozdní doby bronzové s dvojicí nápažníků stejného typu jako z rosického depotu (detailně Salaš 2015). Další známé lokality se nacházejí již ve vzdálenosti větší než 5 km a vzhledem k poměrně hustému pravěkému osídlení regionu jejich rekapitulace na tomto místě není smysluplná (podrobně Belcredi a kol. 1989).

\section{Interpretace depozita}

Všechny nápažníky z rosického depozita (obr. 2, 3) byly jednoznačně intenzivně používány, což dokládá absence výrobních stop, nepravidelné postranní fasety a místy i setřené části výzdoby (např. č. 6). Z morfologického hlediska jde o stejný typ kruhového šperku plankonvexního profilu s mírně dorsálně ovalenými konci, jednotlivé kusy se liší pouze rozměry a výzdobou. Celkově masivní provedení s váhou nad $100 \mathrm{~g}$ odpovídá dobře analogickým kusům popsaným níže, rozměry pak spíše funkci nápažníku než náramku.

Výzdoba této poměrně unifikované skupiny nápažníků sestává ze dvou základních prvků - objevují se svazky obrvených rýh, tedy rýh lemovaných kolmými či šikmými liniemi jemných rýžek, a dále svazky krokvic vyplněných stejnými drobnými rýžkami, které tvoří trojúhelníky či klikatky. Doplňkově se objevují linie rýžek uspořádaných do klikatek a linie drobných vybíjených bodů. Tyto prvky nejsou kombinovány náhodně, objevuje se omezené množství ustálených kompozic, které zde byly jednoduše popsány písmeny (tab. 1), přičemž na drobné variace např. v množství rýh nebyl brán zř̌etel (např. mírná variace ve výzdobě kusủ č. 4 a 6 z Rosic, tedy dvojice nevyplněných rýh navíc u kusu č. 4 , je patrně dána větším rozměrem tohoto exempláře, a tedy i větší plochou $\mathrm{k}$ „,vyplnění“, nebot’ u všech př́padů výzdoba pokrývá kompletní pohledovou plochu šperku v pravidelném rytmu). V depotu z Rosic byly rozlišeny zrcadlově symetrická kompozice A (č. 4, 6), do třetinových polí rozdělená kompozice B (č. 1, 2, 3) a oběžná kompozice $C$ (č. 5). Typ kompozice byl popsán i u dalších publikovaných kompletních kusů z Moravy a z geograficky blízkého depozita z Plaveckého Podhradí I z Malých Karpat (Bartík - Farkaš - Jelinek. 2019, Taf. 5); celý soubor zahrnuje 120 kompletních kusů s dobře zachovanou výzdobou tohoto typu z Moravy a dalších šest kusů z Plaveckého Podhradí. Každý jedinec byl zařazen bud’to k již evidované kompozici, nebo mu bylo prriděleno písmeno nové. Dále byla sledována délka a hmotnost a také specifické značky na středu „rubové“, tedy vnitřní nezdobené strany nápažníku (tab. 1).

Přesnou analogii ke kompozici B z Rosic najdeme na jednom kusu z depotu Malhostovice 1 (Salaš 2005, 399: 5) a na čtyřech kusech z depotu Tišnov 1 (Salaš 2005, tab. 454: 1, 2; 455: 7, 8). Analogie ke kompozici C obsahuje opět depot z Tišnova, a to celkem tři kusy (Salaš 2005, tab. 454: 3, 5; 455: 6), s drobnou odlišností se objevují i v depotu ze Zastávky, odkud pocházejí tři prakticky stejné a jeden jen mírně odlišný kus (Salaš 2005, tab. 467: 7; 468: 11; 470: 20, 22). Právě tišnovský depot je nejlepši analogií k celku z Rosic, byt' jsou jeho nálezové okolnosti a přesná skladba poněkud problematické (Salaš 2005, 463). Pokud přijmeme tezi, že se skutečně jednalo o depozitum 12 kusů nápažníků, k němuž patří všechny dnes dohledatelné kusy (uložené v Moravském zemském muzeu a Východočeském 


\begin{tabular}{|c|c|c|c|c|c|c|}
\hline Lokalita & Kus (číslo) & $\begin{array}{c}\text { Typ } \\
\text { ornamentu }\end{array}$ & $\begin{array}{l}\text { Délka } \\
(\mathrm{mm})\end{array}$ & Váha (g) & Značka & Kontext \\
\hline Rosice 1 & 1 & B & 100 & 118 & 0 & depot \\
\hline Rosice 1 & 2 & $\mathrm{~B}$ & 103 & 113 & 2 & depot \\
\hline Rosice 1 & 3 & B & 150 & 107 & 2 & depot \\
\hline Rosice 1 & 4 & A & 112 & 116 & 0 & depot \\
\hline Rosice 1 & 5 & $\mathrm{C}$ & 122 & 158 & 1 & depot \\
\hline Rosice 1 & 6 & A & 98 & 112 & 0 & depot \\
\hline Plavecké Podhradie 1 & 1 & $\mathrm{D}$ & 102 & 120 & 3 & depot \\
\hline Plavecké Podhradie 1 & 2 & $\mathrm{D}$ & 96 & 118 & 0 & depot \\
\hline Plavecké Podhradie 1 & 3 & A & 96 & 129 & 0 & depot \\
\hline Plavecké Podhradie 1 & 4 & A & 91 & 111 & 0 & depot \\
\hline Plavecké Podhradie 1 & 5 & $\mathrm{D}$ & 93 & 127 & 0 & depot \\
\hline Plavecké Podhradie 1 & 6 & $\mathrm{D}$ & 98 & 120 & 3 & depot \\
\hline Kuřim 1 & 27 & $\mathrm{C}$ & 133 & 105 & 0 & depot \\
\hline Kuřim 1 & 31 & $E$ & 84 & 108 & 0 & depot \\
\hline Kuřim 1 & 33 & $\mathrm{~F}$ & 94 & 102 & 0 & depot \\
\hline Kuřim 1 & 34 & A & 101 & 136 & 0 & depot \\
\hline Kuřim 1 & 35 & G & 92 & 90 & 0 & depot \\
\hline Kuřim 1 & 36 & A & 80 & 95 & 0 & depot \\
\hline Kuřim 1 & 38 & $\mathrm{H}$ & 87 & 114 & 0 & depot \\
\hline Lazce & 3 & I & 75 & 86 & 0 & depot \\
\hline Lazce & 5 & I & 84 & 86 & 0 & depot \\
\hline Lazce & 6 & I & 76 & 61 & 0 & depot \\
\hline Luleč 2 & 1 & A & 102 & 146 & 0 & depot \\
\hline Luleč 2 & 3 & A & 105 & 142 & 1 & depot \\
\hline Luleč 2 & 2 & $\mathrm{~J}$ & 130 & 229 & 2 & depot \\
\hline Luleč 2 & 4 & A & 93 & 140 & 0 & depot \\
\hline Luleč 2 & 5 & A & 97 & 119 & 0 & depot \\
\hline Luleč 2 & 6 & A & 99 & 139 & 0 & depot \\
\hline Luleč 2 & 7 & A & 106 & 138 & 3 & depot \\
\hline Luleč 2 & 8 & A & 97 & 115 & 2 & depot \\
\hline Luleč 2 & 9 & A & 92 & 128 & 0 & depot \\
\hline Luleč 2 & 10 & A & 110 & 167 & 3 & depot \\
\hline Luleč 2 & 11 & A & 106 & 141 & 0 & depot \\
\hline Luleč 2 & 12 & A & 115 & 167 & 3 & depot \\
\hline Luleč 2 & 13 & A & 102 & 153 & 0 & depot \\
\hline Luleč 2 & 14 & A & 93 & 121 & 0 & depot \\
\hline Luleč 2 & 15 & A & 95 & 111 & 1 & depot \\
\hline Luleč 2 & 16 & $\mathrm{~J}$ & 119 & 191 & 2 & depot \\
\hline Luleč 2 & 17 & A & 98 & 131 & 1 & depot \\
\hline Luleč 2 & 18 & A & 96 & 135 & 0 & depot \\
\hline Luleč 2 & 19 & $\mathrm{~A}$ & 106 & 147 & 0 & depot \\
\hline Malhostovice 1 & 3 & A & 101 & 126 & 0 & depot \\
\hline Malhostovice 1 & 5 & B & 121 & 137 & 0 & depot \\
\hline
\end{tabular}

Tab. 1. Základní vlastnosti publikovaných kompletních nápažníků morfologicky a výzdobou odpovídajících kusům z Rosic; exempláře z Moravy a Plaveckého Podhradí (dle Salaš 2005; Halama 2015; Vich 2012; Bartík - Farkaš - Jelínek 2019).

Tab. 1. The basic properties of the published complete armlets with morphology and decoration comparable with finds from Rosice, Moravia and Plavecké Podhradie (after Salaš 2005; Halama 2015; Vích 2012; Bartík - Farkaš - Jelínek 2019). 


\begin{tabular}{|c|c|c|c|c|c|c|}
\hline Lokalita & Kus (číslo) & $\begin{array}{c}\text { Typ } \\
\text { ornamentu }\end{array}$ & $\begin{array}{l}\text { Délka } \\
(\mathrm{mm})\end{array}$ & Váha (g) & Značka & Kontext \\
\hline Myslejovice 1 & 2 & $\mathrm{~K}$ & 117 & 123 & 0 & depot \\
\hline Myslejovice 1 & 3 & $\mathrm{~L}$ & 114 & 116 & 0 & depot \\
\hline Tišnov & 1 & B & 98 & 131 & 0 & depot \\
\hline Tišnov & 2 & $\mathrm{~B}$ & 122 & 123 & 0 & depot \\
\hline Tišnov & 3 & $\mathrm{C}$ & 122 & 165 & 0 & depot \\
\hline Tišnov & 5 & $\mathrm{C}$ & 121 & 157 & 0 & depot \\
\hline Tišnov & 6 & $\mathrm{C}$ & 130 & 182 & 0 & depot \\
\hline Tišnov & 7 & $\mathrm{~B}$ & 105 & 112 & 0 & depot \\
\hline Tišnov & 8 & $\mathrm{~B}$ & 104 & 136 & 0 & depot \\
\hline Tišnov & 9 & $\mathrm{~A}$ & 120 & 106 & 0 & depot \\
\hline Zastávka & 6 & $\mathrm{M}$ & 107 & 139 & 0 & depot \\
\hline Zastávka & 7 & $\mathrm{~K}$ & 94 & 105 & 0 & depot \\
\hline Zastávka & 8 & $\mathrm{~N}$ & 100 & 98 & 8 & depot \\
\hline Zastávka & 4 & $\mathrm{O}$ & 75 & 102 & 0 & depot \\
\hline Zastávka & 5 & $\mathrm{O}$ & 72 & 95 & 0 & depot \\
\hline Zastávka & 9 & $\mathrm{P}$ & 89 & 103 & 0 & depot \\
\hline Zastávka & 10 & $\mathrm{C}$ & 114 & 162 & 0 & depot \\
\hline Zastávka & 11 & $\mathrm{~K}$ & 95 & 93 & 0 & depot \\
\hline Zastávka & 12 & $\mathrm{~N}$ & 84 & 79 & 0 & depot \\
\hline Zastávka & 13 & $\mathrm{~N}$ & 97 & 120 & 0 & depot \\
\hline Zastávka & 14 & $\mathrm{C}$ & 108 & 136 & 0 & depot \\
\hline Zastávka & 15 & $\mathrm{O}$ & 74 & 109 & 0 & depot \\
\hline Zastávka & 16 & $\mathrm{~N}$ & 103 & 118 & 0 & depot \\
\hline Zastávka & 17 & $\mathrm{~N}$ & 94 & 103 & 0 & depot \\
\hline Zastávka & 18 & $\mathrm{~N}$ & 101 & 119 & 0 & depot \\
\hline Zastávka & 19 & $\mathrm{~N}$ & 96 & 94 & 0 & depot \\
\hline Zastávka & 20 & K & 105 & 121 & 0 & depot \\
\hline Zastávka & 21 & $\mathrm{~N}$ & 108 & 138 & 0 & depot \\
\hline Zastávka & 22 & $\mathrm{~K}$ & 98 & 101 & 0 & depot \\
\hline Zastávka & 23 & $\mathrm{~N}$ & 97 & 115 & 0 & depot \\
\hline Zastávka & 24 & $\mathrm{~N}$ & 100 & 93 & 0 & depot \\
\hline Jabloňany & 1 & $\mathrm{~A}$ & 98 & 98 & 0 & depot \\
\hline Jabloňany & 2 & $\mathrm{~A}$ & 96 & 123 & 0 & depot \\
\hline Jabloňany & 3 & A & 104 & 94 & 0 & depot \\
\hline Jabloňany & 4 & Q & 118 & 136 & 0 & depot \\
\hline Jabloňany & 5 & Q & 128 & 179 & 0 & depot \\
\hline Jabloňany & 6 & Q & 116 & 136 & 0 & depot \\
\hline Kelčice 1 & 5 & $\mathrm{R}$ & 112 & 123 & 3 & depot \\
\hline Kelčice 1 & 6 & $\mathrm{~S}$ & 92 & 97 & 0 & depot \\
\hline Kelčice 1 & 7 & $\mathrm{R}$ & 114 & 98 & 0 & depot \\
\hline Kelčice 1 & 8 & $\mathrm{R}$ & 100 & 100 & 1 & depot \\
\hline Kelčice 1 & 9 & $\mathrm{~T}$ & 90 & 100 & 3 & depot \\
\hline Kelčice 1 & 10 & $\mathrm{~T}$ & 103 & 130 & 0 & depot \\
\hline Kelčice 1 & 11 & $\mathrm{R}$ & 117 & 111 & 0 & depot \\
\hline Kelčice 1 & 12 & $\mathrm{U}$ & 101 & 106 & 0 & depot \\
\hline
\end{tabular}

Tab. 1. Pokračování.

Tab. 1. Continued. 


\begin{tabular}{|c|c|c|c|c|c|c|}
\hline Lokalita & Kus (číslo) & $\begin{array}{c}\text { Typ } \\
\text { ornamentu }\end{array}$ & $\begin{array}{l}\text { Délka } \\
(\mathrm{mm})\end{array}$ & Váha (g) & Značka & Kontext \\
\hline Kelčice 1 & 13 & $\mathrm{~V}$ & 106 & 113 & 0 & depot \\
\hline Kelčice 1 & 14 & $\mathrm{R}$ & 107 & 136 & 2 & depot \\
\hline Kelčice 1 & 15 & $\mathrm{R}$ & 107 & 142 & 2 & depot \\
\hline Kelčice 1 & 16 & $\mathrm{R}$ & 108 & 104 & 0 & depot \\
\hline Kelčice 2 & 8 & $\mathrm{R}$ & 121 & 127 & 2 & depot \\
\hline Kelčice 2 & 9 & $\mathrm{U}$ & 97 & 62 & 0 & depot \\
\hline Kelčice 2 & 10 & W & 116 & 136 & 0 & depot \\
\hline Kelčice 2 & 11 & $\mathrm{X}$ & 106 & 109 & 0 & depot \\
\hline Kelčice 2 & 12 & $\mathrm{U}$ & 101 & 92 & 0 & depot \\
\hline Kelčice 2 & 13 & $\mathrm{U}$ & 98 & 76 & 0 & depot \\
\hline Kelčice 2 & 14 & $\mathrm{Y}$ & 108 & 109 & 3 & depot \\
\hline Kelčice 2 & 15 & $\mathrm{U}$ & 96 & 82 & 0 & depot \\
\hline Kelčice 2 & 16 & $\mathrm{U}$ & 98 & 83 & 0 & depot \\
\hline Kelčice 2 & 17 & $\mathrm{U}$ & 96 & 80 & 0 & depot \\
\hline Kelčice 2 & 18 & $\mathrm{Y}$ & 104 & 114 & 0 & depot \\
\hline Kelčice 2 & 19 & $\mathrm{Y}$ & 104 & 114 & 0 & depot \\
\hline Kelčice 2 & 20 & $\mathrm{Z}$ & 117 & 156 & 0 & depot \\
\hline Kelčice 2 & 21 & W & 112 & 148 & 0 & depot \\
\hline Kelčice 2 & 22 & $\mathrm{~T}$ & 106 & 129 & 2 & depot \\
\hline Kelčice 2 & 23 & $\mathrm{U}$ & 98 & 113 & 0 & depot \\
\hline Kelčice 2 & 24 & $\mathrm{U}$ & 102 & 92 & 0 & depot \\
\hline Kelčice 2 & 25 & $\mathrm{U}$ & 100 & 99 & 0 & depot \\
\hline Kelčice 2 & 26 & $\mathrm{U}$ & 97 & 59 & 0 & depot \\
\hline Kelčice 2 & 27 & $\mathrm{U}$ & 94 & 57 & 0 & depot \\
\hline Znojmo & 1 & $\mathrm{AA}$ & 76 & 81 & 0 & depot \\
\hline Znojmo & 2 & $\mathrm{AA}$ & 70 & 80 & 0 & depot \\
\hline Znojmo & 3 & $\mathrm{AA}$ & 10 & 78 & 0 & depot \\
\hline Znojmo & 4 & $\mathrm{AA}$ & 76 & 66 & 0 & depot \\
\hline Znojmo & 5 & $\mathrm{AA}$ & 78 & 70 & 0 & depot \\
\hline Znojmo & 6 & $\mathrm{AA}$ & 69 & 74 & 0 & depot \\
\hline Znojmo & 7 & $\mathrm{AA}$ & 74 & 70 & 0 & depot \\
\hline Znojmo & 8 & $\mathrm{AA}$ & 71 & 77 & 0 & depot \\
\hline Znojmo & 9 & $\mathrm{AA}$ & 72 & 75 & 0 & depot \\
\hline Klentnice hrob 53 & & $\mathrm{AA}$ & 66 & & 0 & hrob \\
\hline Tetčice hrob 3 & & $\mathrm{R}$ & & & 0 & hrob \\
\hline Tetčice hrob 3 & & $\mathrm{R}$ & & & 5 & hrob \\
\hline
\end{tabular}

Tab. 1. Pokračování.

Tab. 1. Continued.

muzeu v Pardubicích), pak pouze zde se objevují právě tři kompozice $\mathrm{A}, \mathrm{B}, \mathrm{a} \mathrm{C}$, tedy stejně jako u celku z Rosic, a počet kusů je přesně dvojnásobný. Stejný počet jako v Rosicích, tedy šest kusů ve dvou koncentracích po třech, tvoři depozitum z Jabloňan 1; zde jsou tři kusy zdobené kompozicí A doplněny třemi kusy se specifickou kompozicí Q, objevující se pouze v Jabloňanech (Malach - Štrof - Hložek 2016, 27, obr. 15-16). Prakticky stejnou kompozici má i depot Plavecké Podhradí I z Malých Karpat, zde jsou dva kusy zdobené kompozicí A doplněny dalšími čtyřmi se specifickou, jinde se neopakující kompozicí D (Bartík - Farkaš - Jelineke 2019, Taf. 5). Kusy zdobené kompozicí C se nacházejí i v početnějším souboru ze Zastávky, zde ovšem v doprovodu exemplářu s dalšími výzdobnými kompozicemi (Salaš 2005, tab. 467-470), z nichž některé se velmi blǐži kompozicím A i B, v detailech jsou ovšem odlišné. 


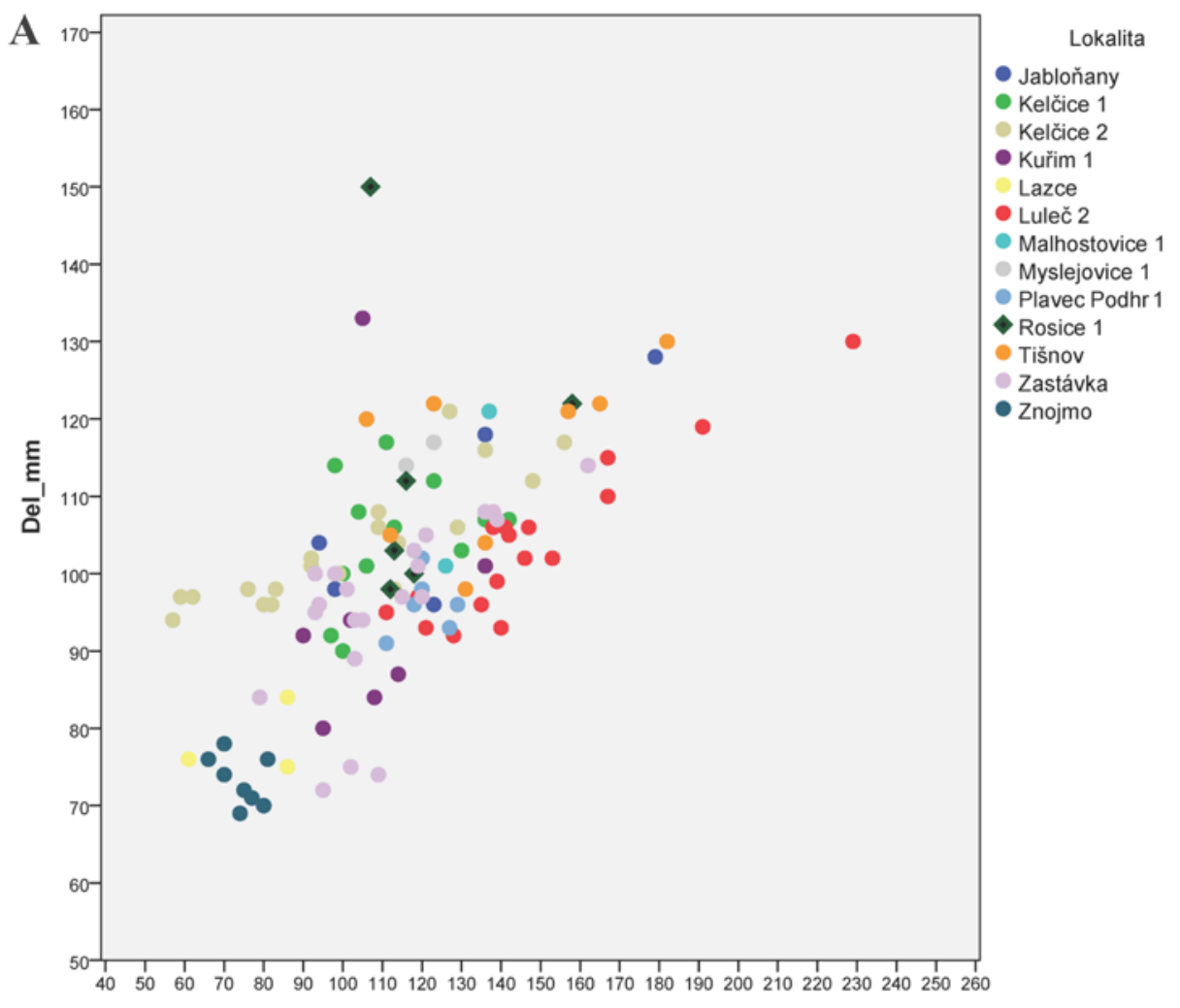

Vaha_g

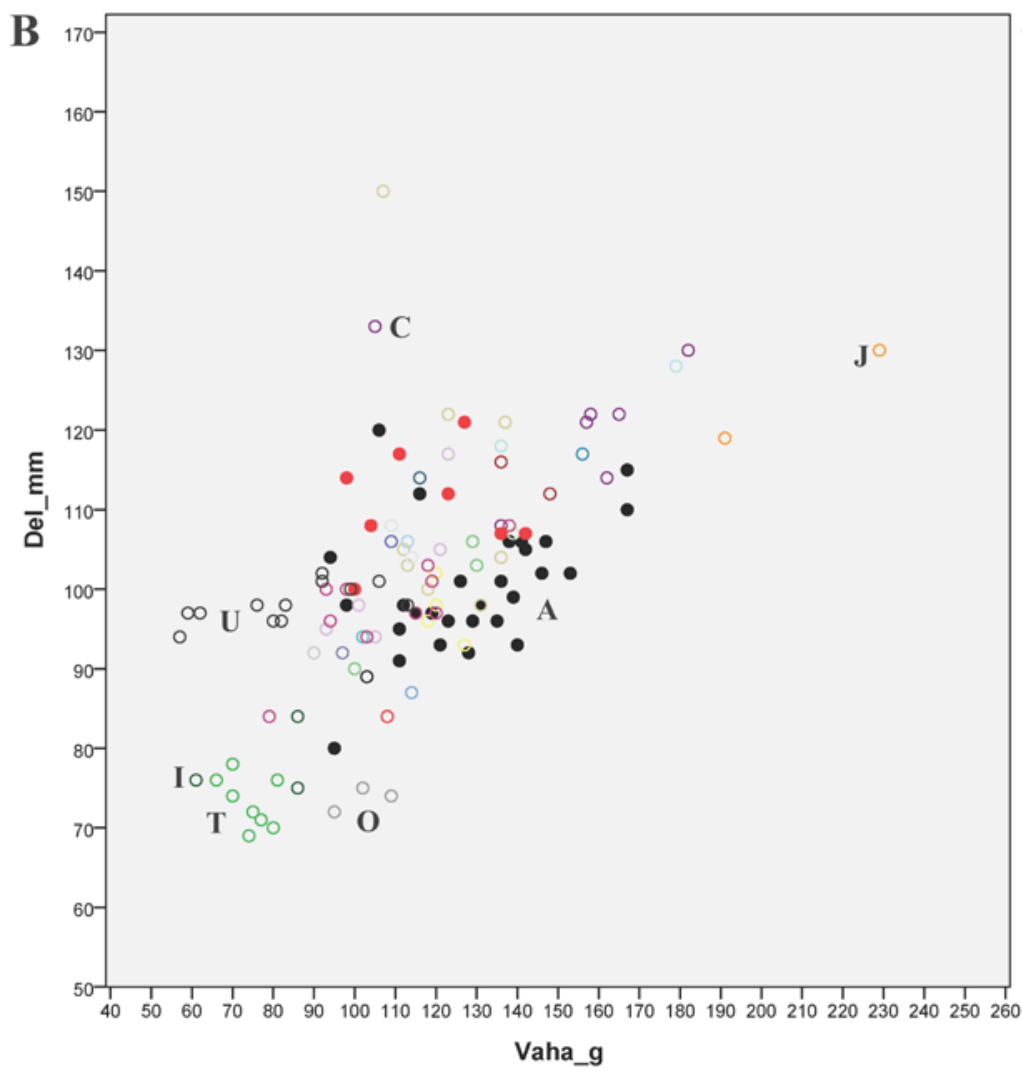

Typ_ornamentu
OA
OAA
B
OC
D
OE
OF
G
OH
OI
OJ
OK
OL
OM
ON
OO
OP
Q
OR
OS
OT
OU
$O V$
$O W$
$O X$
$O Y$
$O Z$

Obr. 4. Srovnání fyzických vlastností a dekoru nápažníků z Moravy a Plaveckého Podhradí 1: A - vyneseny jednotlivé lokality; B - vyneseny jednotlivé kompozice výzdoby (viz tab. 1).

Fig. 4. Comparison of physical properties and decoration of armlets from Moravia and Plavecké Podhradie 1: A - sites; B - composition of decoration (see Tab. 1). 


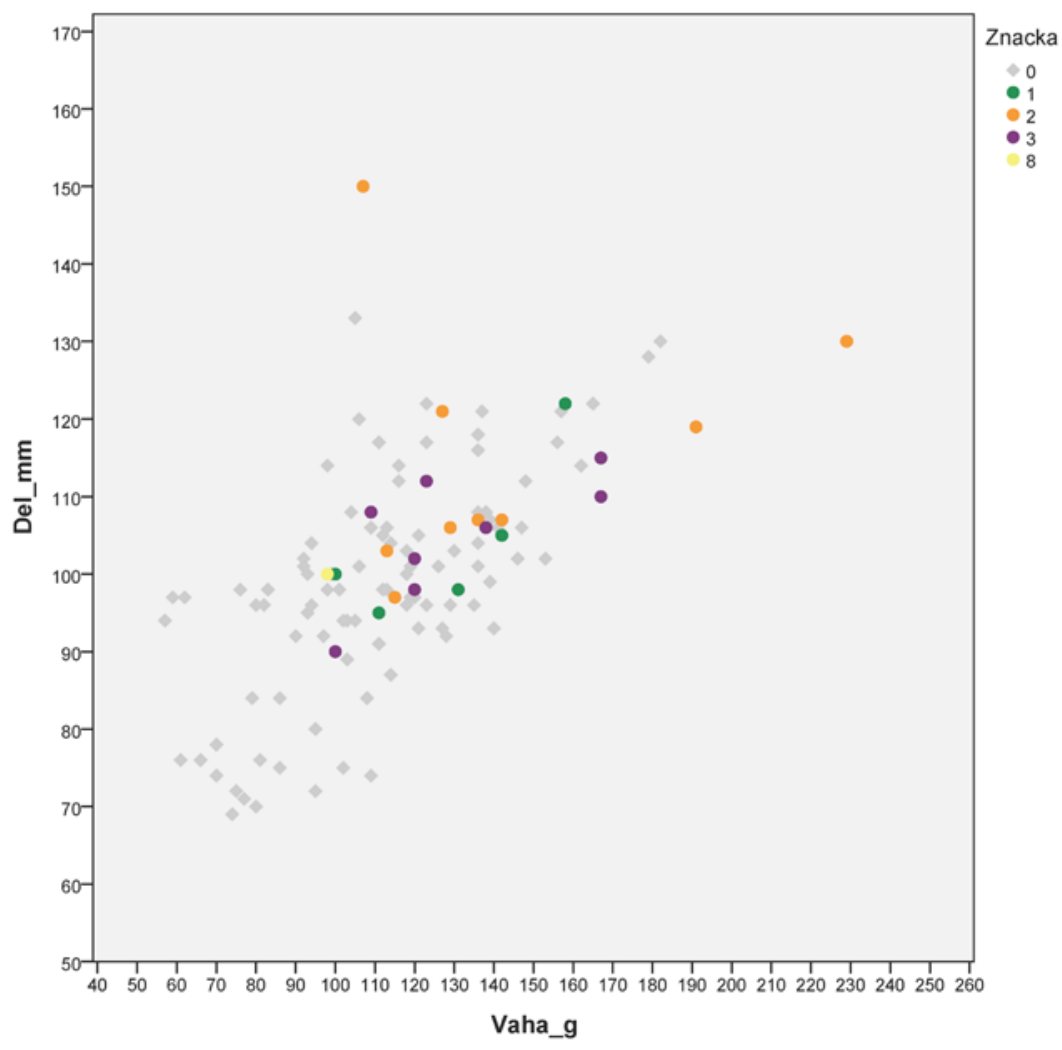

Obr. 5. Srovnání fyzických vlastností a dekoru nápažníků z Moravy a Plaveckého Podhradí 1: vyneseny značky na vnitřní straně, číslo odpovídá počtu rýh.

Fig. 5. Comparison of physical properties and decoration of armlets from Moravia and Plavecké Podhradie 1: displayed the marks on the inner side, the number indicates the number of grooves.

Této skupině náramků se podrobně věnoval M. Salaš, s výjimkou poněkud odlišně zdobených či nekompletních kusů $z$ depotů ze Slatinic a Lešan 2 jsou všechny moravské depotové celky datovány do stupně Ha B1-2 (Salaš 2005, 86-87). Řada z nich je sice tvořena pouze různými typy kruhového šperku a tedy datována per se, jednotlivé kusy z početnějších celků ze širšího středoevropského prostoru však tuto dataci podporuji (Bartík - Farkaš - Jelineke 2019, 61-62).

Převážná část publikovaných moravských exemplárů (celkem 117) pochází z depotů. Nejpočetněji se mezi nimi vyskytují exempláře zdobené výzdobnou kompozicí A (27 kusů ze sedmi depotů a další dva z Plaveckého Podhradî), které mají také nejširší prostorovou distribuci (Bartík - Farkaš - Jelinek. 2019, 61-62, 73, Abb. 28). Všechny ostatní výzdobné kompozice, jakkoliv individuálně početné, spojují vždy maximálně trojici (kompozice B - Rosice, Malhostovice, Tišnov; kompozice $\mathrm{C}$ - Kurim, Tišnov, Zastávka) či dvojici (kompozice $\mathrm{K}$ - Myslejovice, Zastávka) lokalit, a to vždy v poměrně úzce geograficky sevřené oblasti. Ostatní opakovaně se objevující výzdobné kompozice se váží pouze na jedinou lokalitu (kompozice N, R, U, AA). Je zřejmé, že kompozice A je v tomto smyslu zřetelně odlišná, jde svým způsobem o ,ikonické" provedení kopírované či distribuované v širší středoevropské oblasti, patrně s jasně srozumitelným významem. Oproti tomu ostatní výzdobné kompozice můžeme označit spiše za lokální. Pokud budeme sledovat základní rozměrové vlastnosti nápažníků (délka a váha, obr. 4, 5), je ž̌ejmé, že některé depoty obsahují šperky podobných, od ostatních odlišných rozměrů (Znojmo a Lazce drobné kusy, Luleč 2 hmotnější exempláře) a při vynesení do bodového grafu nelze hovořit o středovém shluku s ideální standardizovanou velikostí, ale spiše o individualizované produkci, kde ovšem dochází $\mathrm{k}$ deponování sad s podobnými fyzickými vlastnostmi (obr. 4A). Podobný obraz je zřejmý i z vazby jednotlivých výzdobných kompozic na velikost, která je patrná pouze u několika rozměrově okrajových skupin s distribucí vždy na jediné lokalitě (Kelčice - U, Znojmo - T; obr. 4B). Kusy zdobené kompozicí A nefigurují na okrajových hodnotách a je u nich patrná jistá míra standardizace rozměrů, ovšem se značným rozptylem. 

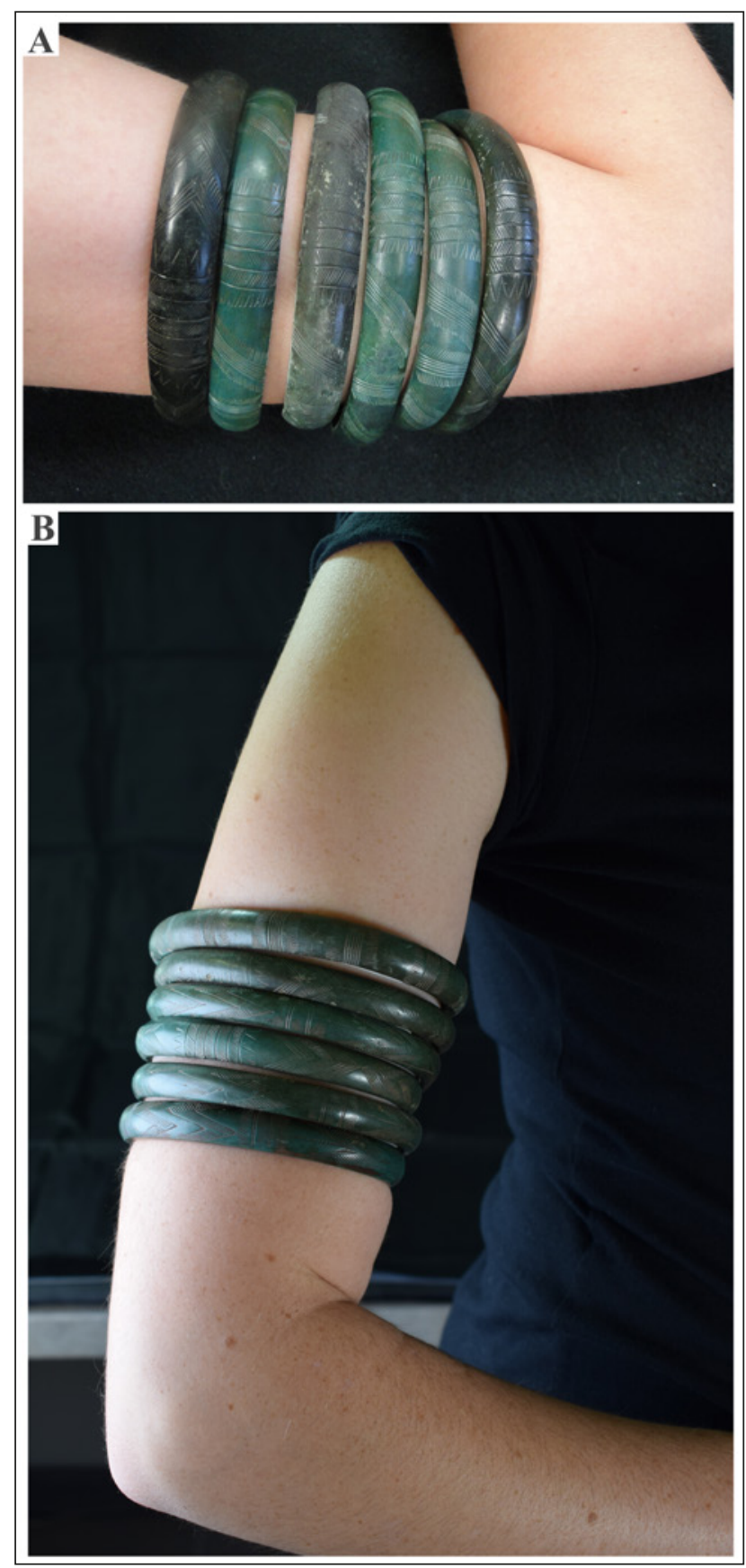

Obr. 6. Sady z depotů Plavecké Podhradie I (A) a Rosice 1

(B) v předpokládané funkční poloze. A - dle Bartík Farkeaś-Jelinek. 2019, Abb. 9; B - foto M. Poláčková.

Fig. 6. The hoards from Plavecké Podhradie I (A) and Rosice 1 (B) in the assumed functional position. A - after Bartík-Farkaš-Jelinek. 2019, Abb. 9; B - photo M. Poláčková.
Jediné tři kusy tohoto typu nápažníků z hrobů pocházejí z Klentnice a Tetčic. Z hrobu 53 z Klentnice pochází rozměrově menší náramek, jehož výzdoba přesně odpovídá jednotnému dekoru všech kusů z depotu ze Znojma, což je nepřekvapivé (Ř́hovský 1965 , Taf. XIII: 53b). Z Tetčic ze žárového hrobu 3/1964 pochází pár totožných nápažníků rozměrově odpovídající kusům z depotů, zdobený jen mírně odlišnou variací na kompozici A. Přesné analogie k této výzdobě neobsahuje žádný z geograficky blízkých celků, ale depoty Kelčice 1 a 2. Oba kusy z Tetčic jsou značeny příčnými záseky na stř̌edu vnitřní plochy, a to pěti u prvního a osmi u druhého exempláre (Říhouský 1966, obr. 94: h, ch; Salaś 2015, obr. V. 32). Ani u jednoho z hrobů není k dispozici antropologická analýza a přímé indicie pro genderovou př́slušnost tohoto typu nápažníků na Moravě tak chybí.

Značky $\mathrm{v}$ podobě rýžek na středu vnitřní strany se objevují celkem na třech kusech z Rosic a na dalších 21 kusech ze sledovaného souboru, podíl takto zdobených kusů je nezanedbatelných 19 \%. Nejčastěji se objevují jedna až tři prríčné či šikmé rýžky, pouze exempláře z hrobu $z$ Tetčic mají pět a osm rýžek a kus č. 8 z depotu ze Zastávky osm oválných záseků (Salaš 2005, tab. 467: 8). Rýžky jsou provedeny jinou, méně precizní technikou než ornament, a lze je nejspíše považovat za jakousi formu kontramarky, tedy druhotného přidání informace na již užívaný předmět. Nemají žádnou jednoznačnou vazbu na rozměry šperku (obr. 5), ani jejich vazba na typ výzdobné kompozice není přímočará, ovšem je nápadné, že pokud se značka váže na konkrétní typ výzdoby, pak vždy jen v rámci jednoho depotu a jde o značky různé. Značky jsou tedy nejpočetnější na kompozicích A (7 ks), ovšem všechny kusy pocházejí z depotu Luleč 2; podobně značky na kompozici $\mathrm{R}$ se sice objevují šestkrát, pět kusů je ovšem z depotů z Kelčic a jediný z hrobu z Tetčic. Ostatní kompozice se $\mathrm{v}$ souboru značených kusů objevují vždy maximálně dvakrát, přičemž $\mathrm{v}$ depotech $\mathrm{z}$ Rosic, Lulče 2 a Plaveckého Podhradí je to právě dvakrát tedy vnitřní značení má opět pár se stejnou výzdobnou kompozicí. Interpretace není jednoduchá, proti teorii o značení kusů v sadě svědčí, že stejně zdobené kusy mají běžně i stejné značky. Podíl značených kusů ve sledovaném souboru je značně vysoký oproti jiným skupinám takto signovaného šperku - přesná kvantifikace sice provedena nebyla, je ovšem žrejmé, že minimálně v moravském prostředí byl typ nápažníků z rosického depotu pro značení „kontramarkou“ preferován (takto již Salaš 2005, 87). 


\section{Závěr}

Soubor bronzových kruhových šperků z Rosic patři k velmi specifické skupině depozit typologicky shodného kruhového šperku, dle rozměrů pravděpodobně nápažníkủ. Šest kusů z Rosic má přesné analogie v depotech z Jabloňan 1 a Plaveckého Podhradí I (obr. O), které zahrnovaly spolehlivě vždy právě jen šest kusů stejného šperku. Je k nim možné přiřadit i depozitum dvanácti nápažníků z Tišnova, avšak s jistou opatrností, nebot’ zde počet artefaktů není zcela jistý. Počty odpovídající násobkům nejnižšího „magického“ lichého prvočísla 3 se ovšem zdají být v tomto př́ípadě již nenáhodné. Všechny tyto celky pojí výskyt vždy jednoho až tří kusů zdobených typem kompozice A, přičemž některé exempláře z různých lokalit mají výzdobu prakticky do detailu totožnou. Kruhové šperky s dorzálně ovalenými konci se objevují i v dalších moravských depotech stupně Ha B1. Pokud se objeví více kusů, pak jde zpravidla o specifické depoty zahrnující pouze součásti kroje (Kelčice 1 a 2, Myslejovice, Nemojany 2, Tišnov, Zastávka), řidčeji se vyskytují i v depotech zahrnujících širší spektrum artefaktů (Kuřim 1), v tomto prrípadě jde častěji o jednotlivé kusy (Kladky 3: Vich 2017; Hrabová 1: Halama 2015). Z hlediska počtu kusů je centrem výskytu Morava, a to s výraznou regionální koncentrací na Brněnsku, Vyškovsku a v Boskovické brázdě, s rostoucí vzdáleností se objevuji již jen páry či jednotlivé kusy (obr. 7; k distribuci v Karpatské kotlině viz Bartík - Farkaš - Jelinek 2019, 62; k distribuci v Čechách viz Kytlicová 2007, 56-58). Garnitura z Plaveckého Podhradí je v tomto ohledu výjimkou, svou roli zde ovšem může hrát kulturní blízkost s centrální oblastí výskytu. Vzhledem k tomu, že prakticky všechny šperky tohoto typu pocházejí z depotů, nemusí se nutně geografická koncentrace nálezů překrývat s oblastí jejich produkce a užívání, může jít prostě jen o region, kde byly nejčastěji obětovány.

Právě pro votivní význam depozit nápažníků popsaného typu lze shrnout několik silných argumentů. Především jde o deponování $\mathrm{v}$ ustálených počtech (6, popř. 12 kusů), dále propojenost řady celků prostřednictvím jedinců zdobených ,ikonickou“ výzdobnou kompozicí A, která vzhledem k ustálenosti nutně musela mít jasný a široce srozumitelný informační význam, a v neposlední řadě preference tohoto typu šperku pro označování na vnitřní straně. Tvar a výzdoba v tomto prípadě tvoří nejen typologickou kategorii pro archeology dneška, ale evidentně i kategorii šperku se specifickým významem ve společnosti původní. Asi nejlépe si lze představit velmi obecnou souvislost s genderem, společenským statusem jedinců, specifickými životními situacemi či návštěvou konkrétního místa, a to nepochybně s odkazem na prŕíslušné mytologické systémy. V tomto kontextu pak docházelo k nevratnému deponování celých garnitur, jež lze vzhledem $\mathrm{k}$ malým počtům považovat spíše za osobní, soukromé obětiny jedinců. Obětovány prítom takto byly šperky evidentně dlouhodobě nošené, tedy patrně standardní součásti kroje (viz též Bartík - Farkaš - Jelineke 2019, 73). K dosavadním interpretacím neprìdává celek z Rosic žádné nové překvapivé skutečnosti, spolu s novými, takřka shodnými celky z Jabloňan a Plaveckého Podhradí ovšem podtrhuje specifičnost celého fenoménu.

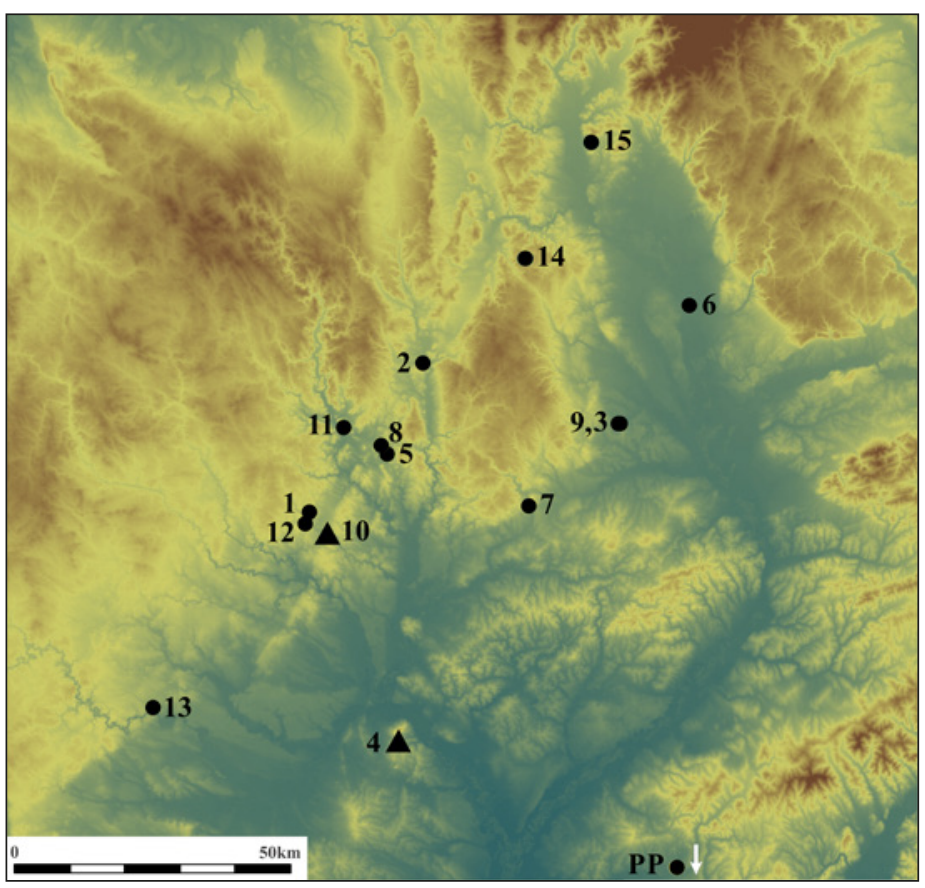

Obr. 7. Distribuce nápažníků s dorzálně ovalenými konci a charakteristickou výzdobou na Moravě: 1 - Rosice 1; 2 - Jabloňany 1; 3 - Kelčice 1 a 2; 4 - Klentnice; 5 - Kuřim 1; 6 - Lazce; 7 - Luleč; 8 - Malhostovice; 9 - Myslejovice; 10 - Tetčice; 11 - Tišnov 1; 12 - Zastávka 1; 13 - Znojmo 1; 14 - Kladky 3; 15 - Hrabová 1; PP - Plavecké Podhradie; bod - depot, trojúhelník - hrob.

Fig. 7. The distribution map of armlets with dorsal oval ends and typical decoration in Moravia; point - deposit, triangle - grave. 


\section{Bibliografie}

Bartík, J. - Farkaš, Z. - Jelinek, P. 2019: Bronzehortfunde aus den Kleinen Karpaten und ihren Vorgebirgsgebieten. In: Bazovský, I. - Březinová, G. (eds.): Ludia a hory - archeologická perspektíva. Interakcie l’udských spoločenstiev horských a podhorských oblastí západného Slovenska. Zborník Slovenského národného múzea - Archeológia Supplementum 12. Bratislava - Nitra, 15-102.

Belcredi, L. a kol. 1989: Archeologické lokality a nálezy okresu Brno-venkov. Brno.

Cǐ̌̌már, M. 2004: Encyklopedie hradišt’ na Moravě a ve Slezsku. Praha.

Halama, J. 2015: Bronzový žebrovaný náramek a rekonstrukce původního nálezového celku depotu Hrabová 1 (okr. Šumperk). In: Ožd’ány, O. (ed.): Popolnicové polia a doba halštatská. Zborník referátov z XII. medzinárodnej konferencie „Doba popolnicových polí a doba halštatská“. Hriňová-Pol’ana 14. - 18. máj 2012. Nitra, 43-54.

Komoróçyy, B. et al. 2019: Společnými silami za poznáním společného archeologického dědictví Jihomoravského kraje. Brno.

Kytlicová, O. 2007: Jungbronzezeitliche Hortfunde aus Böhmen. Prähistorische Bronzefunde XX/12. Stuttgart.

Malach, R. - Strof, A. - Hlǒ̌ěk, M. 2016: Nová depozita kovové industrie doby bronzové v Boskovické brázdě. Pravěk - Supplementum 32. Brno.

Navrátil, A. 2010: Nové nálezy z „Tabulové hory“ u Klentnice a stav archeologické nevědomosti. Přehled výzkumů 51, 97-107.

Říhouský, J. 1965: Das Urnengräberfeld von Klentnice. Fontes Archaeologici Pragenses 8. Pragae.

Říbovský, J. 1966: Lužické pohřebiště v Tetčicích u Rosic. Archeologické rozhledy 18, 263-269.

Salaš, M. 2005: Bronzové depoty střední až pozdní doby bronzové na Moravě a ve Slezsku. Brno.

Salaš, M. 2015: Ve zlatavém lesku doby bronzové. In: Hájek, Z. a kol.: Tetčice. Archeologické doklady lidských aktivit na katastru obce a blízkého okolí. Tetčice, 55-87.

Salaš, M. - Jariškková, Z. 2017: Poznámky k současnému stavu fondu metalických depotů doby popelnicových polí v regionu Malé Hané. Pravěk Nová řada 25, 119-136.

Vich, D. 2012: Kladky - neznámé hradiště na severozápadní Moravě. Možnosti detektorového průzkumu v archeologii. Památky archeologické 103, 233-272.

\section{Summary}

In the last days of March 2020, Mr. Svoboda of Rosice reported the discovery of a hoard of six bronze armlets he had found during a walk with a metal detector in the forest outside Rosice. The location of the find was precisely measured and its documentation was carried out (Fig. 1B). The hoard could no longer be recorded in its original storage, but according to the finder's data, the armlets were stored together, but not arranged on top of each other. 
A minor trench was excavated at the site identified by the finder, which did not detect any indications of a submerged feature or stone structure that could be related to the hoard.

The set of bronze circular jewellery from Rosice belongs to a very specific group of deposits of typologically identical circular jewellery, presumably of armlets by size. Six pieces from Rosice have exact analogies in the hoard from Jabloňany 1 and Plavecké Podhradie I, which reliably included just six pieces of the same jewel at any one time. It is possible to assign to them the hoard of the 12 armlets from Tišnov, but with some caution, as the number of artifacts here is not entirely certain. The numbers corresponding to multiples of the lowest „magic“ odd prime number 3, however, appear to be no longer uniform in this case. All of these are linked to the occurrence of one to three pieces each decorated with type of composition A, with some of the specimens from different locations having virtually identical decorations in detail. Circular jewellery with dorsal ovaled ends also appears in other Moravian hoards of the Ha B1 stage. If multiple pieces appear, then they are generally specific deposits involving only the components of dress (Kelčice 1 and 2, Myslejovice, Nemojany 2, Tišnov, Zastávka), less frequently also in depots involving a wider range of artifacts (Kurim 1), in this case more often only as single pieces (Kladky 3: Vich 2017; Hrabová 1: Halama 2015). In terms of number of pieces, the centre of the occurrence is Moravia, with a strong regional concentration near Brno, Vyškov and Boskovice regions, with increasing distance being more couples or single pieces (for distribution in the Carpathian basin see Bartik - Farkas - Jelinek 2019, 62; for distribution in Bohemia see Kytlicová 2007, 56-58). The Plavecké Podhradie set is an exception in this respect, but cultural proximity with the central area of occurence may play a role. Since virtually all jewellery of this type comes from hoards, the geographical concentration of the finds does not necessarily overlap with the area of their production and use, it may simply be the region where they have been most frequently sacrificed.

It is precisely for the votive importance of armlet hoards of the type described, that several strong arguments can be summarised. Above all, there is the deposit in steady numbers ( 6 or 12 pieces), the interconnectedness of a number of individual pieces through decoration with the ,iconic“ A composition, which, due to its steadiness, was bound to have a clear and widely understood information meaning, and not least the preference for this type of jewellery for marking on the inside. The shape and decoration in this case constitute not only a typological category for archaeologists of today, but evidently a category of jewellery with specific significance in the past society. Perhaps one can best imagine a very general connection with gender, the social status of individuals, specific life situations, or visiting a particular place, no doubt with reference to the respective mythological systems. In this context, there was an irreversible deposit of entire set, which, given the small numbers, can be seen as more personal, private sacrifices of individuals. In doing so, the jewellery was evidently long-worn, presumably the standard components of dress (see also Bartík - Farkaš - Jelinek 2019, 73). The Rosice hoard adds no new surprising facts to the present interpretations, however, along with the new, almost identical, sets of Jabloňany and Plavecké Podhradie underscores the specificity of the whole phenomenon. 